\title{
Influence of Labour-Only Sub- Contracting in Procurement Performance in Public Hospitals in Nakuru County
}

\author{
Esther Wangari Ngigi
}

\begin{abstract}
Although subcontractors are perceived experts in their field, it is not a guarantee that they will meet the contractor's standards. Like in other parts of the country the health sector in Nakuru County has been facing numerous challenges under the devolved systems. Specifically the study sought to establish the influence of labour-only sub-contracting on procurement performance in public hospitals in Nakuru County. Descriptive survey research design was used. The target population was all 80 respondents involved in the procurement process in health facilities. Since the population was small the researcher used census technique to incorporate all the targeted respondents. Questionnaire was used to collect the primary data desirable for the study. Primary data was collected by administering questionnaires to the respondents in the hospitals. Data was analyzed using both descriptive and inferential statistical methods. The study concluded that in most cases specialty sub-contracting result to increased cost of the contract and this influences the performance of the procurement in public hospitals. The researcher concluded that labour-only sub-contracting is usually applicable when time is of essence in the execution of a contract. From the conclusion the researcher recommended that the public hospitals ought to adopt the labor only subcontracting because it is applicable when contract demand special consultancy services and when the execution of the contract is labour intensive.
\end{abstract}

Index Terms - Labour-Only Sub- Contracting, Procurement Performance.

\section{INTRODUCTION}

Contracting in the health sector is generally defined as the development and implementation of a documented agreement by which one party (the principle or purchaser or contractor) provides compensation to another party (the agent or provider or contractee) in exchange for a defined set of health services for a defined target population (England, 2016). Contracts may also specify the types, quantity, and quality of services that the provider is to deliver. Some contracts will specify the intended health outcomes associated with the delivery of the contracted services. McDavid and Clemens (2017) defines Subcontracting as the practice of assigning part of the obligations and tasks under a contract to another party known as a subcontractor.

In the United States, sub-contracting across a range of sectors became popular in the 1990s, and the trend towards offering subcontracts in the health sector has correspondingly been gathering steam. Currently, there is an increasing tendency for government-run Medicaid programs to sub contract with private managed care companies to provide health care for Medicaid beneficiaries (Wooldridge and Hoag, 2018).
In Sub-Saharan African countries, the movement toward subcontracting out of health services has been influenced by the evolution of health care reform ideologies and related efforts by multilateral and bilateral agencies (Mills, 2016). These agencies and reforms support new paradigms about the role of the state in health care provision. Specifically, they emphasize the state's role as a catalyst for competition among providers and as a force that encourages greater utilization of private providers, rather than promoting the state as the dispenser of services itself.

Procurement performance is a measure of identifying the extent to which the procurement function is able to reach the objectives and goals with minimum costs (Van Weele, 2015). The author further noted that there are two main aspects of the procurement performance: effectiveness and efficiency. Procurement effectiveness is the extent to which the previously stated goals and objectives are being met. It refers to the relationship between actual and planned performance of any human activity, (Van Weele, 2015). Additionally, he explains that procurement efficiency is the relationship between planned and actual resources required to realize the established goals and objectives and their related activities, referring to the planned and actual costs. As a result, supplier performance is the most important procurement performance driver.

According to health sector performance report 2013 and 2014 health institutions are ailing from shortage of drugs or holding on expired drugs. Health centers and dispensaries are hardly stocked with the recommended medicines. It indicates that high rate of expired drugs in dispensaries and other public hospitals indicates poor planning and high wastage of public resources in the counties this affects efficient delivery of quality services. Procurement is an important part of efficient management and supply and wastage is critical for all of level care institutions. An effective procurement process ensures the availability of the right Medicals in the right quantities, available at right time for the right patient and at the right prices and at recognizable standards of quality (WHO, 2015).

In Nakuru County, poor quality of service delivery at health facilities led to the formation of the Quality Assurance Steering Committee in the year 2010 whose main objective was to ensure continuous delivery of quality service to the patients through subcontracting. In a survey carried out by the Kenya Anti-Corruption Commission of Kenya (2010), it was revealed that even though the government supplies drugs to facilities most patients in the county were being compelled to buy own drugs and other items such food and equipment's (Kenya Anti-Corruption Commission, 2010). This indicates that the quality of healthcare in these public institutions has greatly declined. 


\section{Statement of the Problem}

Subcontracting is an excellent means for a main contractor to exercise cost control while sharing part of the risk to other people in order to concentrate the effort and resources of main contractor on other activities. Sharing of risk makes the insurance, supervision and management cost of that work to be taken care by the subcontractor which reduces worries of main contractor.

Several factors having been identified to affect cost and time performance of subcontracted projects. Some are; material, equipment's or labor shortage, price fluctuations, and inclination to completion of project in shorter time to catch the acceleration award or to dispatch the equipment to other projects (Frimpong, Oluwoye \& Crawford, 2016). Although subcontractors are perceived experts in their field, it is not a guarantee that they will meet the contractor's standards. At some point the contractor may feel it would have been better had they not outsource for a specific project, especially if they have full knowledge of how things are done. Like in other parts of the country the health sector in Nakuru County has been facing numerous challenges under the devolved systems. With the introduction of county government the procurement procedures in hospitals has greatly changed with majority of contractors opting to sub-contract most of their roles this has been attributed to poor service delivery as some of the sub-contractors don't meet the intended goals and objectives. Therefore the study sought to establish the influence of labour-only sub-contracting on procurement performance in public hospitals in Nakuru County.

\section{Research Hypothesis}

$\mathbf{H}_{\mathbf{0 1}}$ : Labour-only sub-contracting has no significant influence on procurement performance in public hospitals in Nakuru County.

\section{LITERATURE REVIEW}

\section{Theoretical Review}

The study was anchored on the concept of Efficiency Theory.Efficiency Theory was first conceptualized by Richard Posner in the 1970s. It assumes that parties value assets more or less correctly and that their transacting choices are motivated solely by wealth maximization goals (Harry \& Martin. 2006). This theory also assumes the absence of negative externalities. An externality is an effect that a transaction between one set of parties puts on other parties who were not a part of the deal (Ware \& Kynoch, 2013). The theory is relevant to the study in that the contractors, assigned to perform certain task, may lack the necessary skills, or even time may be a limiting towards efficiency delivery of services as a result the contractor will be forced to seek a subcontractor to aid the same services.

\section{Conceptual Framework}

\begin{tabular}{|c|c|}
\hline $\begin{array}{l}\text { Labour-Only } \\
\text { Sub-contracting } \\
\text { • Labor intensive } \\
\text { • Time constraint }\end{array}$ & $\begin{array}{l}\text { Procurement } \\
\text { Performance } \\
\text { - Cost } \\
\text { - Timing } \\
\text { - Quality }\end{array}$ \\
\hline
\end{tabular}

Nominated Sub-Contracting
Labour-only subcontracting, or lump labour, is a type of employment system whereby a contractor would hire, on a labour-only basis, a subcontractor, which is often an individual worker or a collection of individuals, and pay a lump sum for an agreed amount of work. This is a form of self-employment, (Yoon \& Kang, 2016). According to (Rundquist, 2016) labour-only contracting is the procurement of products or services from sources that are external to the organization or as phenomena in which a company delegates part of its in-house operations to a third party with the third party gaining full control over that operation/process. The attractions of labour-only subcontracting are obvious from the viewpoint of the major contractors. Because the labour-only workers are legally self-employed, the major contractors paid no national insurance contributions, sick pay and holiday pay. This implies that they are able to pay workers a higher rate of pay, which in turn allows them to continually recruit the skilled labour that is sometimes in short supply, (Assaad, 2016).

The use of labour subcontracting and non-standard forms of employment has become common practices in many developed countries as well as developing countries (ILO, 2015). These result not from underdevelopment of industry but cost-cut pressure driven of intensified competitions. More and more enterprises have attempted offload cost and risk onto subcontractors. Hughes et al., (2016) ascertained that the sudden surge of labour-only subcontracting in United Kingdom was at 1996 when government introduced selective employment tax (SET) designed to tax firms on their payroll which brought firms and contractors to sought alternatives by employing labour directly which in turn leads to a consequent growth in subletting of labour. Abdullahi (2014) explained that labour-only subcontracting occurs when a firm or person is been employed to supply labourers to perform part of main contractor's work. Main-contractor provides materials, plants and equipment needed to execute the job. CIDB (2017) defined a labour only subcontractor as a person who provides labour to main contractors for the performance of certain work in the construction industry. The main contractor supplies material and pays wages to the labourers. This is done to reduce the financial burden on the subcontractor.

According to Saboia, (2014) agreements between contractors and labour-only workers are individual contracts, which are negotiated outside of the collective bargaining structures of the industry. In labor-only contracting, the statute creates an employer-employee relationship for a comprehensive purpose: to prevent a circumvention of labor laws. The contractor is considered merely an agent of the principal employer and the latter is responsible to the employees of the labor-only contractor as if such employees had been directly employed by the principal employer. A finding by (Connolly, 2016) on labor-only contractor is equivalent to a finding that an employer-employee relationship exists between the company and the labor contractor employee, the relationship being such as provided by the law itself. In technical terms, the principal employer is liable with the labor-only contractor for all the rightful claims of the employees.

\section{Research Gaps}

Okech (2017) investigated the impact of performance contracting on efficiency in procurement performancein the 
public sector. The study revealed existence of a positive and strong relationship between performance sub-contracting and efficiency in the provision of procurement performance realized through decline in operating costs, improved revenue and output, enhanced resource. However, the study focused on the utilization of resources and the challenges facing implementation of performance sub-contracting. While the current study will focus on the specialty sub-contracting, nominated sub-contracting, and labour-only sub-contracting

\section{RESEARCH METHODOLOGY}

The study used descriptive research design. Descriptive survey research design can generate accurate information for a large number of people over a wide area using a small sample. It is used to explore relationships between variables and allows generalizations across populations. The target population was medical officer, procurement officer, anddepartment heads in the user departments and medical officer in charge of the various targeted health facilities, procurement officers and department heads from user departments in sub-county hospital and referral hospital in Nakuru County.Questionnaire was used as the main data collection instrument to collect primary data desirable for the study. A pilot-test was conducted in Nyahururu Hospital, Laikipia County where 8 questionnaires were issued out. Data collected from the pilot study was not incorporated in the main study.Data collected was quantitative in nature. Quantitative data was analyzed by use of Statistical Package for Social Sciences (SPSS) version 24. Both descriptive and inferential statistics were used in the study. Descriptive statistics involved the use of percentages, frequencies, measures of central tendencies (mean) and measures of dispersion (standard deviation). Inferential statistic was used to determine the relationship between variables.

\section{DATA ANALYSIS, FINDINGS}

\section{INTERPRETATIONS}

\section{Response Rate}

The study administered 80 questionnaires for data collection. However, 62 questionnaires were properly filled and returned. This represented 78 percent overall successful response rates. Respondents were also assured of confidentiality of the information provided. .

\section{Demographic Information}

Table 1: Duration Worked in the Current Organization

\begin{tabular}{|c|c|c|}
\hline Duration of Service & Frequency & Percentage \\
\hline Less than 3 Years & 13 & $21 \%$ \\
\hline 3-9 Years & 30 & $49 \%$ \\
\hline $9-12$ Years & 14 & $23 \%$ \\
\hline More than 12 years & 5 & $7 \%$ \\
\hline Total & 62 & 100 \\
\hline \multirow{2}{*}{\multicolumn{2}{|c|}{$\begin{array}{l}\text { According to the findings, } 49 \% \text { of the respondents } \\
\text { indicated that they had been working in their current } \\
\text { organization for } 3-9 \text { years, } 23 \% \text { stated they had been working } \\
\text { in their current organization for } 9-12 \text { years, } 21 \% \text { stated they } \\
\text { had been working in their current organization for less than } 3 \\
\text { years while } 7 \% \text { stated they had been working in their current } \\
\text { organization for more than } 12 \text { years. This shows that majority } \\
\text { of the respondents had been working in their current }\end{array}$}} & $\begin{array}{l}\text { individual has worked determines his/her capacity. } \\
\text { Employees who have longer working experience tend to have } \\
\text { better skills. In this study majority of the respondents have } \\
\text { worked for more than } 3 \text { years indicating they were more } \\
\text { conversant with contracting aspects under study } \\
\text { Descriptive Findings and Discussions }\end{array}$ \\
\hline & & $\begin{array}{l}\text { Labor-Only Sub-Contracting on } \\
\text { Performance in Public Hospitals }\end{array}$ \\
\hline
\end{tabular}
organization for more than 3 years. The duration of service an

Table 2:Labor-Only Sub-Contracting on Procurement Performance in Public Hospitals

\begin{tabular}{|c|c|c|c|c|c|c|}
\hline Labor-Only Sub-Contracting & $\begin{array}{l}\mathrm{A} \\
\%\end{array}$ & $\begin{array}{l}\mathrm{U} \\
\%\end{array}$ & $\begin{array}{l}\mathrm{D} \\
\%\end{array}$ & $\begin{array}{l}\text { SD } \\
\%\end{array}$ & Mean & Std \\
\hline $\begin{array}{l}\text { Labour-only sub-contracting is applicable when the execution of } 50 \\
\text { the contract is labour intensive }\end{array}$ & 31 & 11 & 8 & 0 & 4.226 & 0.948 \\
\hline $\begin{array}{l}\text { In most cases specialty sub-contracting result to increased cost of } \\
\text { the contract }\end{array}$ & 42 & 3 & 0 & 0 & 4.516 & 0.565 \\
\hline $\begin{array}{l}\text { Labour-only sub-contracting is applicable is usually applicable } \\
\text { when time is of essence in the execution of a contract }\end{array}$ & 34 & 0 & 0 & 0 & 4.645 & 0.482 \\
\hline $\begin{array}{l}\text { Specialty sub-contracting is effective when the contract is time } \\
\text { constrained }\end{array}$ & 48 & 0 & 0 & 0 & 4.516 & 0.504 \\
\hline
\end{tabular}

According to the findings majority of the respondents $(81 \%)$ agreed that labour-only sub-contracting is applicable when the execution of the contract is labour intensive with a mean of 4.226 . Majority of the respondents $(97 \%)$ also agreed with a mean of 4.516 that in most cases specialty sub-contracting result to increased cost of the contract. Majority of the respondents (100\%) further agreed that labor-only sub-contracting is usually applicable when time is of essence in the execution of a contract suppliers with a mean of 4.645. Finally majority of the respondents (100\%) agreed that specialty sub-contracting is effective when the contract is time constrained with a mean of 4.516. The standard deviation ranged between 0.482 to 0.948 indicating that majority of the respondents agreed with the issues raised. The findings are in line with Abdullahi (2014) explained that labour-only subcontracting occurs when a firm or person is been employed to supply labourers to perform part of main contractor's work. Main-contractor provides materials, plants 
Influence of Labour-Only Sub- Contracting in Procurement Performance in Public Hospitals in Nakuru County

and equipment needed to execute the job.

Procurement Performance of the Public Hospitals

Table 3:Procurement Performance of the Public Hospitals

\begin{tabular}{|c|c|c|c|c|c|c|c|}
\hline \multirow[t]{2}{*}{ Procurement Performance } & $\mathbf{S A}$ & $\mathbf{A}$ & $\mathbf{U}$ & D & SD & Mean & Std \\
\hline & $\%$ & $\%$ & $\%$ & $\%$ & $\%$ & & \\
\hline \multicolumn{8}{|c|}{ Services procured meet the specified quality } \\
\hline & 37 & 34 & 10 & 16 & 3 & 3.855 & 1.185 \\
\hline services onlered are wortny the c & 55 & 34 & 8 & 3 & 0 & 4.403 & 0.778 \\
\hline \multicolumn{7}{|c|}{ Services are delivered within the stipulated timelines } & 0.738 \\
\hline \multicolumn{7}{|c|}{ Patients are satisfied with the service provided } & 0.807 \\
\hline \multicolumn{8}{|c|}{$\begin{array}{l}\text { According to the findings majority of the respondents } \\
(71 \%) \text { agreed that services procured meet the specified } \\
\text { quality with a mean of } 3.855 \text {. Majority of the respondents } \\
(89 \%) \text { also agreed that services offered are worth the cost with } \\
\text { a mean of } 4.403 \text {. They further agreed }(90 \%) \text { that services are } \\
\text { delivered within the stipulated timelines indicated with a } \\
\text { mean of } 4.307 \text {. In addition majority of the respondents }(81 \%) \\
\text { agreed that customers are satisfied with the service provided } \\
\text { with a mean of } 4.145 \text {. Majority of the respondents ( } 88 \%) \text { also } \\
\text { agreed that general patient satisfaction surveys are conducted } \\
\text { with a mean } 4.387 \text {. The standard deviation ranged between } \\
0.607 \text { to } 1.185 \text { indicating that majority of the respondents } \\
\text { agreed with the issues raised. The findings concurs with }\end{array}$} \\
\hline & & \multicolumn{6}{|c|}{ Procurement Performance } \\
\hline \multirow[t]{3}{*}{ Labor-Only Sub-Contracting } & Pearson Correlation & & .44 & & & & \\
\hline & Sig. (2-tailed) & & .00 & & & & \\
\hline & $\mathrm{N}$ & & 62 & & & & \\
\hline
\end{tabular}

**. Correlation is significant at the 0.05 level (2-tailed).

The study as shown in Table 4.15 established that a moderate positive correlation existed between labor-only sub-contracting and procurement performance $(\mathrm{r}=0.441$; $\mathrm{p}<$ $0.05)$. The results of the correlation analysis indicated that an improvement in labor-only sub-contracting results to improved procurement performance. The $\mathrm{p}$-value was less than 0.05 therefore according to the results, the hypothesis that: Labor-only sub-contracting have no significant influence on employee performance in the public hospitals in Nakuru County, Kenya was rejected. The findings is in agreement with Bannerman., Obeng \& Ahwireng (2017) who established that labor only subcontracting have a significant positive correlation with procurement performance

\section{Hypothesis Testing}

The study sought to test the hypothesis that: $\mathbf{H}_{\mathbf{0 1}}$ : Labour-only sub-contracting has no significant influence on procurement performance in public hospitals in Nakuru County.From the findings the p-value was 0.022 which was less the 0.05 significant level. Therefore, based on the rule of significance, the study rejects the null hypothesis $\left(\mathrm{H}_{03}\right)$ and concluded that Labour-only sub-contracting have a significant influence on procurement performance in the public hospitals in Nakuru County Kenya.

\section{CONCLUSION}

From the findings the researcher concluded that in most cases specialty sub-contracting result to increased cost of the contract and this influences the performance of the procurement in public hospitals. The researcher concluded that labour-only sub-contracting is usually applicable when time is of essence in the execution of a contract. Finally the researcher concluded that specialty sub-contracting is effective when the contract is time constrained and this affects the performance of the procurement in the public hospitals.

\section{RECOMMENDATIONS}

Basing on the conclusions the study recommended that the public hospitals ought to adopt the labor only subcontracting because it is applicable when contract demand special consultancy services and when the execution of the contract is labour intensive. This leads to reduction in the cost of services ameliorates the procurement performance of the public hospitals.

\section{Suggestions for Further Research}

The researcher suggested that a study should be conducted on time and cost performance of labour only subcontracting and 
performance of procurement in the health sectors.

\section{REFERENCES}

[1] Abdullahi, A. H., (2014). Review of Subcontracting Practice in Nigeria construction industry: Journal of environmental sciences and Resource management, 6 (1): 23-33

[2] Assaad, S. (2016). Critical Review of Literature on Performance Contracting. GlobalJournal of Commerce \& Management Perspective (GJCMP). 3(6), 65-70.

[3] CIDB (2017). Subcontracting in the South Africa Construction Industry: Opportunities for Development. Construction industry development board. www.cidb.org.za

[4] Connolly, A. (2016). Performance Target Levels and Effort: Reciprocity across Single- and Repeated-Interaction Settings. Journal of Management Accounting Research, 27(2), 145-164.

[5] England, P. (2016). Planning Performance Based Contracts Considering Reliability and Uncertain System Usage. Journal of the Operational Research Society, 63(10), 1467-1478

[6] Frimpong, W., Oluwoye, P., \& Crawford, A. (2016). Effects of Target Setting in Performance Contracting on Employees Performance in Kenyan Public Enterprises. 20th IBIMA Conference, Kuala Lumpur, Malaysia, 25-26

[7] Harry, L., \& Martin, S. (2006). Measurement of Productivity and Efficiency: Theory and Practice. Cambridge: Cambridge University Press.

[8] Hughes, W., Gray, C. \& Murdoch, J. (2016). Construction Subcontracts: For What We Are About To Receive. In: 7th Annual Construction Law Conference, "Risk, Management and Procurement in Construction”, Centre For Construction Law and Management Kings College London. 413-442

[9] McDavid, C., \& Clemens, L. (2017). Measuring Mutual Confidence in UK Construction Projects. Journal of Management in Engineering, 12 (1): 26-33

[10] Mills, O. (2016). Optimizing the Time and Performance of Subcontractors in the Building Projects. Australian Journal of construction, Economics and Building, 10(1/2): 90-102.

[11] Okech, K. (2017). A framework for Subcontractor Integration In Alliance Contracts. International Journal of Construction Supply Chain Management. 2(1): 17-33

[12] Rundquist, Y. (2016). Best Practices in Managing Specialist Subcontracting Performance: Final report submitted to Construction Industry Institute, Hong Kong.

[13] Saboia, S. (2014). Reducing Rework to enhance project performance levels. Proceedings of one day seminar on "Recent developments in Project management, Hong Kong.

[14] Ware, K., \& Kynoch, F. (2013). Efficiency, asymptotic", in Hazewinkel, Michiel(ed.), Encyclopedia of Mathematics, Springer Science Business Media B.V. / Kluwer Academic Publishers.

[15] Yoon, P., \& Kang, V. (2016). Nominated Subcontractors on International Projects: Approaches to Risk Allocation. A presentation to the Overseas Construction Association of Japan Incorporation, (OCAJI) 